\title{
Use of an ultrasound device to determine sex and to perform gonad biopsy in the European eel Anguilla Anguilla
}

\author{
Uso de um dispositivo ultrasonográfico para determinar o sexo e efetuar a biópsia das \\ gônadas da Enguia-Européia Anguilla anguilla
}

\author{
Dariusz KUCHARCZYK ${ }^{1}$; Daniel ŻARSKI ${ }^{1}$; Sławomir KREJSZEFF ${ }^{1}$; Joanna NOWOSAD ${ }^{1}$; \\ Maria BIŁAS ${ }^{1}$; Katarzyna TARGOŃSKA ${ }^{1}$; Katarzyna PALIŃSKA-ŻARSKA ${ }^{1}$
}

\author{
${ }^{1}$ University of Warmia and Mazury in Olsztyn, Department of Lake and River Fisheries, Olsztyn - Poland
}

\begin{abstract}
The European eel Anguilla anguilla is a highly important market species which is also increasingly in danger of extinction in Europe. One of the ways of protecting the species in the natural environment, while maintaining its market supply, is its aquaculture, e.g. due to much higher survival rate under controlled conditions than in the wild. However, this can be done only when an effective artificial reproduction biotechnique is developed. The aim of this study was to use an ultrasound device to determine the sex and to perform a biopsy of the gonads, which is a part of complete protocol of eel artificial reproduction. The findings indicate that ultrasonography is highly useful in determining the sex in migrating eel (100\% of sureness) and in performing high-precision biopsy of the gonads. The present method gives the possibility to quick determine the maturity of the female gonads. The application of ultrasonography (USG) is totally safe for fish and a portable ultrasound device can be used in both the laboratory and in the field.
\end{abstract}

Keywords: European eel. Oocytes. Maturation. Sex. Ultrasonography. USG.

\section{Resumo}

A Enguia-Européia Anguilla anguilla é uma espécie de grande importância comercial e que apresenta também grande risco de extinção na Europa. Uma das formas para a proteção das espécies em seu ambiente natural e de manter o seu suprimento no comércio é a aquicultura, por exemplo, devido à taxa de sobrevivência em condições controladas ser muito superior a existente em condições naturais. Contudo isto só pode ser obtido quando é desenvolvida uma biotécnica de reprodução artificial eficiente. $\mathrm{O}$ presente trabalho foi delineado para utilizar um dispositivo ultrassonográfico a fim de determinar o sexo e de possibilitar a realização de biópsias das gônadas, o que é parte do protocolo complete de reprodução artificial de enguias. As constatações indicaram que a ultrassonografia é muito útil para a determinação do sexo das enguias (100\% de exatidão) e também é capaz de possibilitar a realização de uma biópsia das gônadas de alta precisão. O método descrito oferece possibilidades para a rápida determinação da maturidade das gônadas das fêmeas. A aplicação da ultrassonografia é totalmente segura para peixes e o dispositivo portátil de ultrassonografia pode ser utilizado tanto no laboratório como em condições de campo.

Palavras-chave: Enguia-Européia. Maturação. Sexo. Ultrassonografia. USG.

Correspondence to:

Dariusz Kucharczyk

University of Warmia and Mazury in Olsztyn, Department of Lake and River Fisheries

Al. Warszawska 117A, 10-718

Olsztyn-Kortowo, Poland

e-mail: dariusz.kucharczyk@uwm.edu.pl

Received: $16 / 11 / 2015$

Approved: 06/04/2016

\section{Introduction}

The market for the European eel (Anguilla Anguilla) in Europe is huge but this eel is a species increasingly in danger of extinction in Europe (FREYHOF; KOTTELAT, 2010; VOGEL, 2010). One of the probable causes of this is a reduction in the number of eel brooders which reach the spawning grounds in the Sargasso Sea area (CLEVESTAM et al., 
2011). This is caused by a number of factors, including high fishing pressure and intensive parasitic infestation caused by Anguillicoloides crassus (LEFEBVRE et al., 2013). Palstra et al. (2007) estimated the energy expenditure in infested fish to increase by as much as $20 \%$. This is important because studies of migrations of the European eel (AARESTRUP et al., 2009) have shown that the fish do not choose the shortest route to reach the spawning ground, but they first swim towards the west coast of Africa and then turn west towards the Sargasso Sea. Moreover, considerable vertical migrations (between the depth of 150 and $600 \mathrm{~m}$ ) have been observed during their migrations (AARESTRUP et al., 2009). Therefore, one may suppose that some spawners, whose physical condition has worsened, may find it difficult to reach the spawning ground or that the quality of gametes they produce will be very low. This has been confirmed by Clevestam et al., (2011), who showed that a considerable number of female eel from the Baltic Sea stand a low chance of making it to the spawning ground. So, the only chance to save the species is the application of combined efforts regarding passive and active protection of this eel species. However, the features associated with the reproduction of this species occurred under controlled conditions. It is a species with very high fecundity (DĘBOWSKA et al. 2015), so it is possible that after a very precise development of reproductive biotechnology and larviculture, it will be possible to produce the European eel in fish farms, which will allow for additional protection of this species.

One of the ways of protecting the European eel in the natural environment, while maintaining its market supply, is through its aquaculture. If the fish is cultured and not collected from nature, it might help to protect eel. But the stocking material (glass eel), both from restocking and culture, until now was collected from the nature. During last three decades, the European eel population decreased rapidly, probably between $90-99 \%$. For this reason, in many
European countries, natural water is stocked (VOGEL, 2010). But this process might be not enough because from year to year the number of collected eel juveniles in nature continues to decrease. However, this can be achieved only when effective biotechniques of artificial reproduction, followed by the rearing of larvae, is developed. Freshwater eels migrate to seas for reproduction. This journey is long both in distance and in time. Under controlled conditions, it is very difficult to involve maturation without hormonal stimulation and much more difficult to obtain viable larvae. Under controlled conditions, the changes (stimulation) only by environmental factors, e.g. temperature, salinity, photoperiod in captivity are not enough for involving gonads and gametes maturation (NOWOSAD et al., 2014). Females usually need about 20 hormonal injections to involve final oocytes maturation. Ovulation in eel is stimulated by administering stimulants at the appropriate size and stage of oocytes maturation (PALSTRA et al., 2005; FURUITA et al., 2009; OLIVEIRA; HABLE, 2010; NOWOSAD et al., $2014,2015)$. Oocytes are usually collected by gonad biopsy. However, oocytes are frequently not collected until several biopsies (punctures) have been performed, which makes the method exceptionally invasive; it may also reduce the survival rate of spawners to $30-70 \%$. Moreover, the eel sex is sometimes identified by means of a biopsy, although females usually grow much bigger than males. However, it has been shown when catching fish starting their spawning migration that females infested by Anguillicola crassus are small and may not differ in size from males (CLEVESTAM et al., 2011). All this has resulted in low effectiveness and high mortality rates during attempts at artificial reproduction of European eel (PEDERSEN, 2003; PALSTRA et al., 2005; HORVÁTH et al., 2011; PÉREZ et al., 2011). Therefore, attempts at improving artificial reproduction should involve, above all, developing a method of determining fish sex without 
negatively affecting their health and gonad biopsies performed as non-invasively as possible.

The aim of this study was to use an ultrasonographic (USG) device to determine the sex and to perform a biopsy of the gonads.

\section{Material and Methods}

European eel (40 specimens), which had started their spawning migration and had been caught in north-eastern Poland (the Baltic Sea basin), were used as the study material. After being caught, the fish were transported to a laboratory where they were put into 1000L tanks with controllable environmental conditions, temperature and photoperiod (KUJAWA et al., 1999). In the hatchery, the fish were kept in fresh water at $12^{\circ} \mathrm{C}$. The photoperiod was $12 \mathrm{~h}(12$ Light: 12 Dark). The fish were not given any food for at least 5 days prior to the experiment.

In order to conduct an anatomical analysis, ten fish of each sex were selected randomly; they were subsequently made collapse by bathing them in a solution of MS-222 (Argent, USA) (200 $\left.\mathrm{mg} \mathrm{L}^{-1}\right)$. Their abdomens were then cut lengthwise from the pectoral fins to the half of the tail part (halfway between the rectal hole and the end of the body). The inside of the body cavity was photographed for further analyses of the positions of each internal organ. Subsequently, three gonad samples were collected from each individual (from the head, central and perirectal area of gonads) and placed on a microscope slide; subsequently, a small amount of Serr's liquid (70\% ethanol, $40 \%$ formaldehyde and $99.5 \%$ glacial acetic acid in the proportion 6:3:1) was added to clarify cytosol and to increase contrast in the observed tissues. A cover slip was then used to make a crushed preparation, which was photographed under a stereoscopic microscope (Leica MZ 16, Germany). This procedure was used because tissues collected from females and males looked similar in a macroscopic image and it was impossible to determine their sex based on it. A photograph of the fish body cavity was used to determine the position of gonads, liver, swimming bladder and stomach, which were used to develop the sex determination diagram. Also, the gonadosomatic index (GSI, mass of gonads * 100 / body weight) was calculated.

Ten fish were selected randomly for USG analyses. After being anaesthetized in an MS-222 solution (200 $\left.\mathrm{mg} \mathrm{L}^{-1}\right)$ they were put on a wet sponge with their abdomen upwards. A USG examination was conducted with a portable SonoSite USG device (M-Turbo model, $5 \mathrm{MHz}$ ). Based on an earlier analysis of the position of body organs, the appearance of the main body organs in a USG image was determined. After locating the gonad tissue, the place was selected in which the gonad tissue was the thickest and its distance from the liver and the stomach was the greatest. This was where biopsy was performed. Moreover, the sex determination diagram based on anatomical analyses was used to determine the sex of the fish. Subsequently, a fine-needle USGguided biopsy was conducted. The tissue samples were then analyzed under a microscope by the crushed preparation method with Serr's liquid (as described above) in order to confirm the sex identification. The fish were then put back to the tanks. The fish survival rate was determined ten days after these procedures. 


\section{Results and Discussion}

\section{Determination of the eel sex}

USG was found to be effective in determining the sex of fish in a study conducted with sturgeon by Masoudifard et al. (2011) and Petochi et al. (2011). The effectiveness of sex determination was found to exceed $95 \%$ in sexually immature fish and $100 \%$ in mature fish. Examination of eel spawners with USG did not reveal any differences in the location of gonads between males and females. In both cases, gonads stretch between the head and beyond the rectal hole. However, there is a great difference in the stage of development - the size of gonads in fish starting their spawning migration. The gonadosomatic index in females ranges from 1.2 to 1.8 , while it is merely 0.1 in males. Therefore, ovaries are perfectly visible, both macroscopically (Figure 1) and in a USG image (Figure 2).
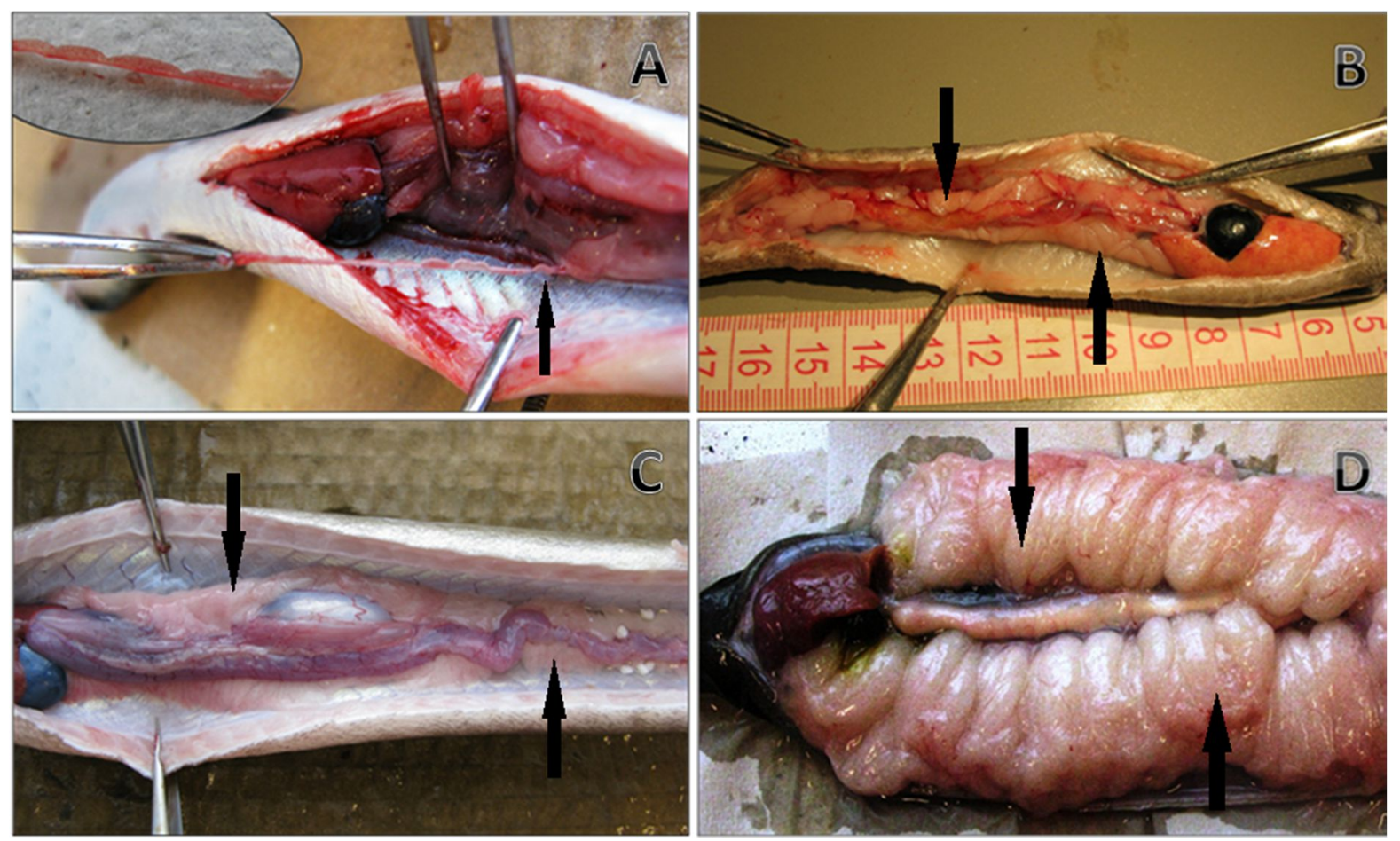

Figure 1 - The testis of European at the beginning of migration $(A)$ and after hormonal treatment $(B)$ and ovary at the beginning of migration (C) and after hormonal treatment (D). The arrows indicated gonads

Male gonads are practically invisible in a USG image as they are only as thick as a hair (Figures 3 and 4). This allowed for practically error-free identification of the sex without having to perform a highly-invasive biopsy. An analysis of tissue samples from gonads confirmed the $100 \%$ effectiveness of determination of sex in eel. There was also no need to use a biopsy more than once to take tissue samples. In the present study, the survival after biopsy was $100 \%$, but the fish need antibiotic treatment. 


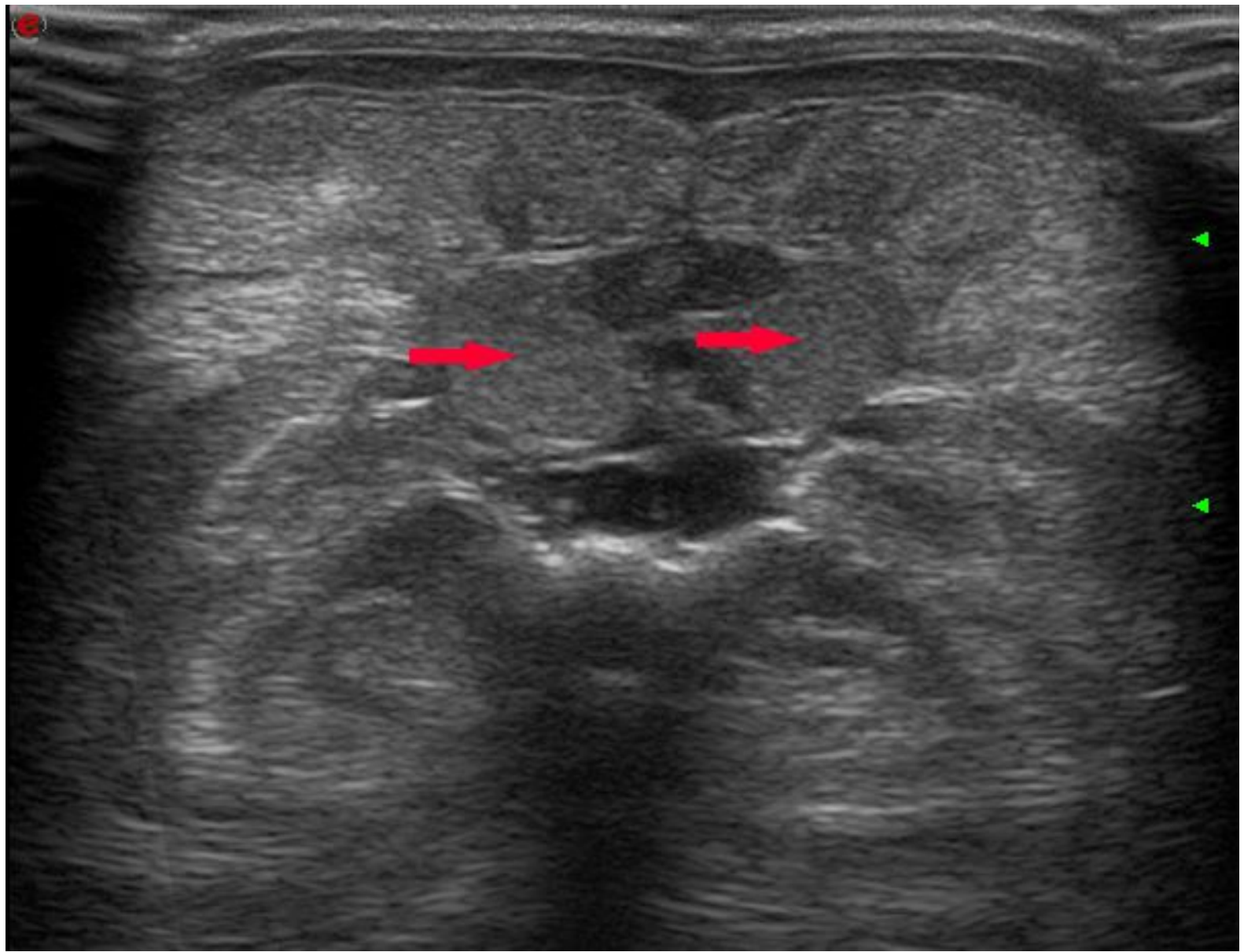

Figure 2 - Ultrasound image from the biopsy site - a cross section of a female body cavity (the gonad is shown by an arrow)

\section{Biopsy}

The data from reports published to date, along with the authors' own research (PALSTRA et al. 2005; HORVÁTH et al., 2011; NOWOSAD et al. 2014, 2015), indicate that the effectiveness of artificial reproduction of eel depends closely on the maturity of gonads. The maturity of ovaries in eel can be determined by biopsy or by such indicators as an increase in body weight index - BWI (NOWOSAD et al. 2014, 2015). Since biopsy is an invasive method, it is important that its precision is as high as possible, which helps to reduce its invasiveness. A USG analysis was used as the basis for selecting the rear section of the gonad for the biopsy (immediately before the rectal hole), where the tissue thickness was the greatest and other organs, such as liver or stomach, were at a certain distance. Performing a USG-guided biopsy at this site is easier than elsewhere. The screen preview helps to introduce the biopsy needle precisely into the gonad (Figure 5) and take a sample with one puncture. The high effectiveness of one puncture helps to significantly reduce the invasiveness of the gonad maturity determination method. After the experiment, the fish were kept for 10 days. No disease symptoms or deaths were observed at that time. 


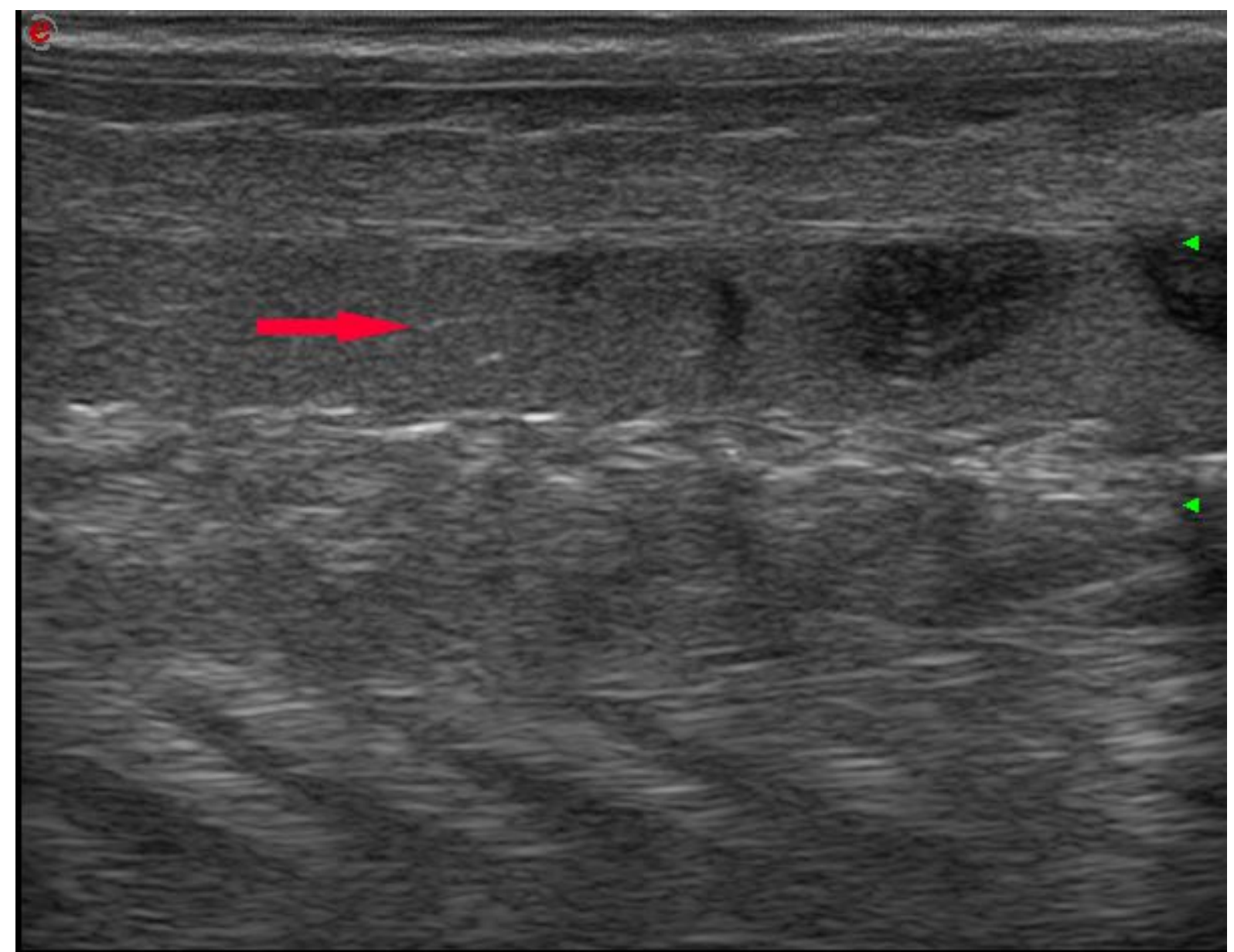

Figure 3 - Ultrasound image from the biopsy site - a lengthwise section of a female body cavity (the gonad is shown by an arrow)

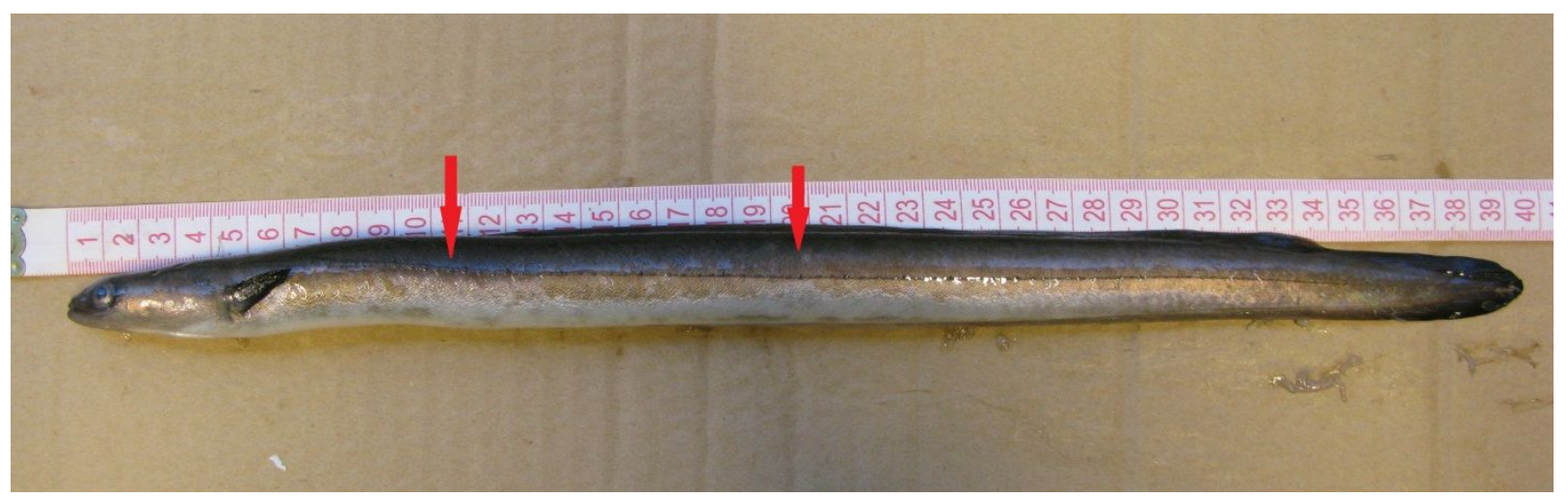

Figure 4 - A male eel. Arrows indicate male biopsy site

\section{Conclusions}

The findings indicate that ultrasonography is highly useful for determining sex in migrating eel and in performing high-precision gonad biopsy. It is a method of low invasiveness, which allows the maturity of female gonads to be determined quickly. A portable ultrasound device can be used both in the laboratory and in the field. 


\section{Acknowledgements}

This study was partially supported by the projects: "Innovations in finfish aquaculture with special reference to reproduction" (InnovaFish),

\section{References}

AARESTRUP, K.; ØKLAND, F.; HANSEN, M. M.; RIGHTON, D.; GARGAN, P.; CASTONGUAY, M.; BERNATCHEZ, L.; HOWEY, P.; SPARHOLT, H.; PEDERSEN, M. I.; MCKINLEY, R. S. Oceanic spawning migration of the European eel (Anguilla anguilla). Science, v. 325, n. 5948, p. 1660, 2009. doi: http://dx.doi.org/10.1126/science.1178120.

ClEVESTAM, P. D.; OGONOWSKI, M.; SJÖBERG, N. B.; WICSTRÖM, H. Too short to spawn? Implications of small body size and swimming distance on successful migration and maturation of the European eel Anguilla anguilla. Journal of Fish Biology, v. 78, n. 4, p. 1073-1089, 2011. doi: http://dx.doi.org/10.1111/j.1095-8649.2011.02920.x.

DĘBOWSKA, M.; NOWOSAD, J.; TARGOŃSKA, K.; ŻARSKI, D.; BIŁAS, M.; ŁUCZYŃSKA, J.; KUCHARCZYK, D. Fecundity of migrating European eel (Anguilla anguilla) from Polish waters. Italian Journal of Animal Sciences, v. 14, n. 3, p. 566571, 2015. doi: http://dx.doi.org/10.4081/ijas.2015.3898.

FREYHOF, J.; KOTTELAT, M. Anguilla anguilla. In: IUCN. IUCN red list of threatened species. 2010. Version 2013.2. <http://www.iucnredlist.org/details/60344/1>. Viewed: 15 Jan. 2014.

FURUITA, H.; ISHIDA, T.; SUZUKI, T.; UNUMA, T.; KUROSAWA, T.; SUGITA, T.; YAMAMOTO, T. Vitamin content and egg quality of eggs produced by broodstock injected with vitamin $\mathrm{C}$ and vitamin $\mathrm{E}$ during artificial maturation in Japanese eel Anguilla japonica. Aquaculture, v. 289, n. 3-4, p. 334339, 2009. doi: http://dx.doi.org/10.1016/j.aquaculture.2009.01.032.

HORVÁTH, L.; SZÉKELY, C.; BOCZONÁDI, Z.; MÉSZÁROS, E.; BERCSÉNYI, M.; URBÁNYI, B.; MÜLLER, T. Induced oogenesis of the European eel (Anguilla anguilla L.) in freshwater condition. Acta Biologica Hungarica, v. 62, n. 4, p. 485-488, 2011. doi: http://dx.doi.org/10.1556/ABiol.62.2011.4.13.

KUJAWA, R.; KUCHARCZYK, D.; MAMCARZ, A. A model system for keeping spawners of wild and domestic fish before
Operational Programme Sustainable Development of the Fisheries Sector and Coastal Fishing Areas 2007-2013 (OR14-61724-OR1400003/09/10/11).

artificial spawning. Aquacultural Engineering, v. 20, n. 2, p. 85-89, 1999. doi: http://dx.doi.org/10.1016/S0144-8609(99)000047.

LEFEBVRE, F.; FAZIO, G.; MOUNAIX, B.; CRIVELLI, A. J. Is the continental life of the European eel Anguilla anguilla affected by the parasitic invader Anguillicoloides crassus? Proceedings of the Royal Society B, v. 280, n. 1754, 2013. doi: http://dx.doi.org/10.1098/rspb.2012.2916.

MASOUDIFARD, M.; VAJHI, A. R.; MOGHIM, M.; NAZARI, R. M.; NAGHAVI, A. R. SOHRABNEJAD, M. High validity sex determination of three-year-old cultured beluga sturgeon (Huso huso) using ultrasonography. Journal of Applied Ichthyology, v. 27, n. 2, p. 643-647, 2011. doi: http://dx.doi.org/10.1111/j.1439-0426.2011.01726.x.

NOWOSAD, J.; KUCHARCZYK, D.; CZARKOWSKI, T. K.; KWASEK, K. Changes in body weight and eye size in female European eel kept in fresh and salt water. Italian Journal of Animal Science, v. 13, n. 2, p. 382-386, 2014. doi: http://dx.doi.org/10.4081/ijas.2014.3144.

NOWOSAD, J.; KUCHARCZYK, D.; ŁUCZYŃSKA, J.; TARGOŃSKA, K.; CZARKOWSKI, T. K.; BIŁAS, M.; KREJSZEFF, S.; HORVÁTH, L.; MÜLLER, T. Changes in European eel ovary development and body and ovary chemistry during stimulated maturation under controlled conditions: preliminary data. Aquaculture International, v. 23, n. 1, p. 13-27, 2015. doi: http://dx.doi.org/10.1007/s10499014-9794-2.

OLIVEIRA, K.; HABLE, W. E. Artificial maturation, fertilization and early development of the American eel (Anguilla rostrata). Canadian Journal of Zoology, v. 88, n. 11, p. 1121-1128, 2010. doi: http://dx.doi.org/10.1139/Z10081.

PALSTRA, A. P.; COHEN, E. G. H.; NIEMANTSVERDRIET, P. R. W.; VAN GINNEKEN, V. J. T.; VAN DEN THILLART, G. E. E. J. M. Artificial maturation and reproduction of European silver eel: Development of oocytes during final maturation. Aquaculture, v. 249, n. 1-4, p. 533-547, 2005. doi: http://dx.doi.org/10.1016/j.aquaculture.2005.04.031. 
PALSTRA, A. P.; HEPPENER, D. F. M.; VAN GINNEKEN, V. J. T.; SZEKELY, C.; VAN DEN THILLART, G. E. E. J. M. Swimming performance of silver eels is severely impaired by the swim-bladder parasite Anguillicola crassus. Journal of Experimental Marine Biology and Ecology, v. 352, n. 1, p. 244-256, 2007. doi: http://dx.doi.org/10.1016/j.jembe.2007.08.003.

PEDERSEN, B. H. Induced sexual maturation of the European eel Anguilla anguilla and fertilisation of the eggs. Aquaculture, v. 224, n. 1-4, p. 323-338, 2003. doi: http://dx.doi.org/10.1016/S0044-8486(03)00242-4.

PÉREZ, L.; PEÑARANDA, D. S.; DUFOUR, S.; BALOCHE, S.; PALSTRA, A. P.; VAN DEN THILLART, G. E. E. J. M.; ASTURIANO, J. F. Influence of temperature regime on endocrine parameters and vitellogenesis during experimental maturation of European eel (Anguilla anguilla) females. General and Comparative Endocrinology, v. 174, n. 1, p. 5159, 2011. doi: http://dx.doi.org/10.1016/j.ygcen.2011.08.009.

PETOCHI, T.; DI MARCO, P.; DONADELLI, V.; LONGOBARDI, A.; CORSALINI, D.; BERTOTTO, D.; FINOIA, M. G.; MARINO, G. Sex and reproductive stage identification of sturgeon hybrids (Aciperser naccarii $x$ Acipenser baerii) using different tools: ultrasounds, histology and sex steroids. Journal of Applied Ichthyology, v. 27, n. 2, p. 637-642, 2011. doi: http://dx.doi.org/10.1111/j.1439-0426.2011.01715.x.

VOGEL, G. Europe tries to save its eels. Science, v. 329, n. 5991, p. 505-507, 2010. doi: http://dx.doi.org/10.1126/science.329.5991.505. 